\title{
Reflections on Direct Access to the African Court on Human and Peoples' Rights: A Cul De Sac?
}

Sidney Tambasi Netya and Cynthia Gathoni Miano*

\begin{abstract}
Individuals and NGOs can directly access the African Court on Human and Peoples' Rights if the state against which a case has been filed has made an optional declaration granting this access. Alternatively, they can access the Court if the African Commission on Human and Peoples' Rights refers communications to it. However, two main barriers have riddled this structure. One, the few states that had made the optional declaration have begun to rapidly withdraw from it. Two, the African Commission, which was expected to mitigate such a situation where few states are making the optional declaration, is hardly referring cases to the Court. This paper examines these two barriers in tandem. It argues that if this status quo is sustained, then, sooner rather than later, this path treaded may lead the African human rights system to a cul-de-sac - back to a onetier system, composed of an accessible Commission and a Court inaccessible to both individuals and NGOs. Drawing lessons from the European and InterAmerican Human Rights system, it recommends preventing this eventuality by amending the African Commission's 2020 Rules of Procedure to provide for a default procedure of referral of cases from the Commission to the Court.
\end{abstract}

Key words: African Court on Human and Peoples'Rights; African Commission on Human and Peoples'Rights; individuals; Non-Governmental Organisations (NGOs); Article 34(6) declaration; direct access, sovereignty and jurisdiction.

\footnotetext{
* The authors are fourth year LLB students at Kenyatta University School of Law. They would like to thank Arnold Nciko and the SLR editorial team for their guidance in the process of writing the paper.
} 


\section{Table of Contents}

I. Introduction

II. A Historical Examination of the African Court Protocol's Provision on Direct Access for Individuals and NGOs

III. Direct Access to the African Court through Article 5(3) of the Protocol: A Report on the Current Status of Article 34(6) Declarations and the Surge in Withdrawals

i. The nature of Article 34(6) declarations.

ii. An epoch of rapid withdrawals

a. Rwanda.

b. Tanzania.....

c. Benin

d. Côte d'Ivoire

iii. Conclusion....

IV. The African Commission as an Avenue for Direct Access to the African Court

i. Referral of cases by the African Commission to the African Court

a. African Commission on Human and Peoples' Rights v

Great Socialist People's Libyan Arab Jamahiriya ......

b. The African Commission on Human and Peoples' Rights v Republic of Kenya

c. The African Commission on Human and Peoples' Rights v Libya

ii. Instance in which the Commission should have referred cases to the Court but failed to make the referral.....

iii. Comparative study with the European and Inter-American buman rights systems.

V. Recommendations

VI. Conclusion 


\section{Introduction}

The African Charter on Human and Peoples' Rights (Banjul Charter) is the foundation of the African regional human rights system. ${ }^{1}$ It was adopted in 1981 by the Organisation of African Unity (OAU) and entered into force in 1986, ${ }^{2}$ to organise protection of human rights in Africa into a structured institutional framework. ${ }^{3}$ Many scholars have provided various perspectives on the reasons that led to the adoption of the Banjul Charter. Misha Ariana Plagis and Lena Riemer classify these perspectives into two. ${ }^{4}$ On one hand, Edward Kannyo provided an optimistic account that, among other factors, African heads of states and political actors benevolently wanted to create a regional human rights system. This system was, inter alia, to address the gross human rights violations on the continent. ${ }^{5}$

On the other hand, there are those who oppose the assumption of benevolence from these political actors. For instance, Kofi Oteng Kufuor attributes the decision to a 'complex interplay of factors' interested in 'the quest for legitimacy by African governments; the rise of an increasingly active civil society within the OAU's member states; and the strategic role that international organizations play'. ${ }^{6}$ However, Plagis and Riemer, taking into account these opposing perspectives, argue that the reality of the Banjul Charter's adoption lies somewhere in between. ${ }^{7}$

The Banjul Charter created the African Commission on Human and Peoples' Rights (African Commission) which was favoured over the creation of a court. ${ }^{8}$ The Banjul Charter mandated it to promote and protect human and

1 Mutua M, 'The African human rights system: A critical evaluation', Human Development Report Office, Nairobi, 2000, 1.

2 Mutua M, 'The African human rights system: A critical evaluation', 1.

3 Okere O, 'The protection of human rights in Africa and the African Charter on Human and Peoples' Rights: A comparative analysis with the European and American systems' 6(2) Human Rights Quarterly, 1984, 141.

4 Plagis M and Riemer L, 'From context to content of human rights: The drafting history of the African Charter on Human and Peoples' Rights and the enigma of Article 7', Journal of the History of International Law, 2020, 12 - https://brill.com/view/journals/jhil/aop/article-10.1163-15718050-12340173/ article-10.1163-15718050-12340173.xml on 30 September 2020.

5 Kannyo E, 'The Banjul Charter on Human and Peoples' Rights: Genesis and political background' in Welch M (ed) Human rights and development in Africa, Albany State University of New York Press, 1984, 128-151; Plagis M and Riemer L, 'From context to content of human rights', 12.

6 Kofi Oteng K, The African buman rights system: Origin and evolution, Palgrave Macmillan, London, 2010, 18.

Plagis M and Riemer L, 'From context to content of human rights', 15.

8 Article 30, African Charter on Human and Peoples' Rights, 28 June 1981; Ssenyonjo M, 'Direct access to the African Court on Human and Peoples' Rights by individuals and nongovernmental organisations:

Vol. 6:1 (2021) p. 105 
peoples' rights in Africa, to interpret the Charter upon request by a State Party, an OAU institution or an African Organization which is recognised by the OAU, and to conduct any other functions as may be entrusted to it by the OAU Assembly. ${ }^{9}$

The Banjul Charter's favouring of a Commission has been called one of the clearest manifestations of African states' unwillingness to relinquish their sovereignty. ${ }^{10}$ Plagis and Riemer note that the drafters of the Charter were aware that, at the time, it would have been too much to ask the African heads of states for a Court. ${ }^{11}$ Nonetheless, they foresaw the possibility of establishing it later by an additional protocol to the Banjul Charter. ${ }^{12}$

Indeed, in 1998, the OAU adopted the Protocol to the African Charter on Human and Peoples' Rights on the Establishment of an African Court on Human and Peoples' Rights (the African Court Protocol). ${ }^{13}$ This decision was a culmination of the fact that almost every independent African state then had established a formal national judicial system and of the mounting pressure from civil society as well as from the African Commission itself. ${ }^{14}$ The African Court Protocol established the African Court on Human and Peoples' Rights (African Court) to complement the role of the African Commission in protecting human and peoples' rights in Africa. ${ }^{15}$

The Commission fulfils its protective mandate through its missions, by settling disputes, by considering communications, through its state reporting mechanism including non-governmental organisations (NGOs) shadow reports, by hearing urgent appeals and through the activities of special rapporteurs and working groups. ${ }^{16}$ The African Court complements the Commission by entitling the Commission to submit cases to the Court, requesting the Commission's opinion when deciding on the admissibility of cases filed to the Court by

An overview of the emerging jurisprudence of the African Court 2008-2012' 2 International Human Rights Law Review, 2013, 21.

9 Article 45, African Charter on Human and Peoples' Rights.

10 Plagis M and Riemer L, 'From context to content of human rights', 17.

11 Plagis $\mathrm{M}$ and Riemer L, 'From context to content of human rights', 17.

12 Ssenyonjo M, 'Direct access to the African Court on Human and Peoples' Rights by individuals and non-governmental organisations', 21.

13 Plagis $\mathrm{M}$ and Riemer L, 'From context to content of human rights', 17.

14 Ssenyonjo M, 'Direct access to the African Court on Human and Peoples' Rights by individuals and non-governmental organisations', 22; Bekker G, 'The African Court on Human and Peoples' Rights: Safeguarding the interests of african states' 51(1) Journal of African Law, 2007, 159.

15 Article 1-2, Protocol to the African Charter on Human and Peoples' Rights on the Establishment of an African Court of Human and People's Rights, 10 June 1998; Ssenyonjo M, 'Direct Access to the African Court on Human and Peoples' Rights by individuals and non-governmental organisations', 18.

16 - https://www.achpr.org/mandateofthecommission on 28 January 2021; Part III, Rules of Procedure on the African Commission on Human and Peoples' Rights (2010).

Vol. 6:1 (2021) p. 106 
individuals and NGOs, transferring cases to the Commission, transmitting notification of each of its judgments to the Commission and consulting it while drafting its rules of procedure. ${ }^{17}$

The African Court Protocol grants the African Commission, state parties to the Protocol and African Intergovernmental Organisations unfettered direct access to the African Court. ${ }^{18}$ The Protocol also allows state parties to make an optional declaration under Article 34(6) accepting the competence of the African Court to admit cases filed directly to it by individuals and by NGOs with observer status before the African Commission. ${ }^{19}$ While the African Court Protocol gives the African Court three types of jurisdiction, that is, contentious, advisory, and conciliatory, ${ }^{20}$ the scope of this paper is only limited to its contentious jurisdictional regime.

This jurisdictional regime creates a paradox: for the primary victims of human rights violations and, therefore, the main beneficiaries of the African Court ${ }^{21}$ to directly seek redress from it, states have to grant them permission through the optional declaration. ${ }^{22}$ This is despite the fact that African states have historically been grievous human rights violators. ${ }^{23}$ As discussed elsewhere in this paper, this direct access jurisdictional architecture was designed to guard African states' sovereignty by disallowing individuals and NGOs' unfettered direct access to the Court.

This restriction affects civil society NGOs, the main advocates for states' compliance with human rights treaties. ${ }^{24}$ Factors such as lack of legal expertise, poverty and limited resources available for legal aid make it difficult for individuals

17 Rule 128(2), Rules of Procedure of the African Commission on Human and People's Rights (2020); Article 2, 5(1)(a), 6, 29(1), 33, Protocol to the African Charter on Human and Peoples' Rights on the Establishment of an African Court of Human and People's Rights.

18 Article 5 (1), Protocol to the African Charter on Human and Peoples' Rights on the Establishment of an African Court of Human and People's Rights.

19 Article 34(6), 5(3), Protocol to the African Charter on Human and Peoples' Rights on the Establishment of an African Court of Human and People's Rights.

20 Eno R, 'The jurisdiction of the African Court on Human and Peoples' Rights' 2(2) African Human Rights Law Journal, 2002, 225.

21 Ssenyonjo M, 'Direct access to the African Court on Human and Peoples' Rights by individuals and non-governmental organisations', 26.

22 Wiseberg S, 'Human rights in Africa: Toward the definition of the problem of a double standard' 6(4) A Journal of Opinion, 1976, 10. Article 5(3), 34(6), Protocol to the African Charter on Human and Peoples' Rights on the Establishment of an African Court of Human and People's Rights.

23 Mutua M, 'The African human rights court: A two-legged stool?' 21(1) Human Rights Quarterly, 1999, 343.

24 Clapham A, 'The use of international human rights law by civil society organisations' in Scott Sheeran, Sir Nigel Rodley (eds) Routledge Handbook of International Human Rights Law, Routledge, Oxfordshire, 2013, 155. 
to access regional human rights institutions in Africa. In the African Court's context, NGOs with observer status before the African Commission step in to file cases on their behalf. ${ }^{25}$ The alternative access path to the African Court is through the Commission which may refer cases to the Court on four grounds. That is, when a state has failed to comply with its recommendations or request for provisional measures, when it comes to the knowledge of a situation that, in its view, constitutes serious or massive human rights violations or at any stage of examining a communication. ${ }^{26}$

Nsongurua J. Udombana observes that NGOs and individuals have the highest need to make use of the African Court and that states are unlikely to support this direct access. ${ }^{27}$ The Court's statistics indeed show that most cases have been filed directly by individuals and NGOs. ${ }^{28}$ Makau Mutua notes that the primary purpose of a human rights court is to protect citizens against the power of the state and its agencies. ${ }^{29}$ The African Court, in particular, was established to complement the protective mandate of the Commission, as well as to strengthen human rights protection in Africa, ${ }^{30}$ and to adjudicate disputes against states alleged to have violated the Banjul Charter and other human rights instruments they have ratified. ${ }^{31}$

Therefore, it may seem counteractive that the instrument creating this Court places the main channel of accessing it in the willingness of states to first ratify the Protocol and subsequently make the Article 34(6) declaration. Du Plessis and Stone argue that this structure may be a major impediment to the essential reason for the African Court's establishment-access to justice for all human rights violations victims in Africa. They argue that the potential fatality of this is not incurable but is mitigated by the African Commission's power to directly refer cases to the African Court, giving individuals and NGOs an extra avenue to get to the Court. ${ }^{32}$ However, as will become clear, this alternative path has proven unreliable.

25 Ssenyonjo M, 'Direct access to the African Court on Human and Peoples' Rights by individuals and non-governmental organisations', 44.

26 Rule 118, Rules of Procedure on the African Commission on Human and Peoples' Rights (2010).

27 Udombana J, 'Toward the African Court on Human and Peoples' Rights: Better late than never' 3(1) Yale Human Rights and Development Journal, 2000, 99.

28 - https://www.african-court.org/cpmt/statistic on 19 January 2020.

29 Mutua M, 'The African human rights system: A critical evaluation', 28.

30 Ssenyonjo M, 'Direct access to the African Court on Human and Peoples' Rights by individuals and non-governmental organisations', 26.

31 Eno R, 'The jurisdiction of the African Court on Human and Peoples' Rights', 225-226.

32 Du Plessis M and Stone L, 'A court not found?' 7(2) African Human Rights Law Journal, 2007, 540.

Vol. 6:1 (2021) p. 108 
While Viljoen specifically placed the African Commission as the main means of access to the African Court, Julia Harrington accurately predicted a low likelihood of African states making an extra effort to provide their citizens and civil society groups with avenues to hold them accountable for their human rights obligations. ${ }^{33}$ Even with Viljoen's conviction that the majority of cases getting the African Court will first begin as communications to the African Commission, he drew comparison with the Inter-American experience to express scepticism to the effect that it was risky to rely on the African Commission to refer as many cases as possible to the African Court. ${ }^{34}$ The Inter-American Commission on Human Rights (Inter-American Commission) had hardly referred any cases to the Inter-American Court of Human Rights (Inter-American Court) in the latter's first decade of operation..$^{35}$ If anything, history has confirmed his scepticism.

This paper addresses the direct access jurisdictional regime of the African Court by individuals and NGOs. It recognises that the decision to make the Article 34(6) declaration is heavily reliant on the political goodwill of African states. While it may have been necessary to include the optional declaration in order to incentivise states to ratify the African Court Protocol, ${ }^{36}$ this has hindered access to the Court by primary victims of human rights violations. A great majority of African states are reluctant to make the Article 34(6) declaration, and even the few that had done so have begun to withdraw from it rapidly. Of the thirty AU members that have ratified the African Court Protocol, ${ }^{37}$ only ten have made the declaration and already four have withdrawn. ${ }^{38}$

Simultaneously, the African Commission which was touted as the cushion for this possibility is hardly referring any cases to the African Court. ${ }^{39}$ At the time of writing, the African Court had received a total of three hundred and ten cases, out of which the African Commission has only referred three. ${ }^{40}$

The central claim of the paper is piggybacked on these two barriers to accessing the African Court: the rapid withdrawals and the African Commission's

\footnotetext{
33 Viljoen F, 'A human rights court for Africa, and Africans' 30 Brooklyn Journal of International Law, 2004, 23; Harrington J, 'The African Court on Human and Peoples' Rights' in Evans M and Murray R (eds) The African Charter on Human and Peoples' Rights: The system in practice, 1986-2000, Cambridge University Press, Cambridge, 2002, 319.

34 Viljoen F, 'A human rights court for Africa, and Africans', 23-24.

35 Viljoen F, 'A human rights court for Africa, and Africans', 25.

36 Udombana J, 'Toward the African Court on Human and Peoples' Rights: Better late than never', 87; Mutua M, 'The African human rights court', 355.

37 - https://www.african-court.org/wpafc/basic-information/ on 28 January 2020.

38 -https://www.african-court.org/wpafc/declarations/ on 9 January 2020.

39 - https://www.african-court.org/cpmt/statistic on 10 January 2020.

40 - https://en.african-court.org/index.php/cases on 28 January 2020.
}

Vol. 6:1 (2021) p. 109 
reluctance to refer cases to the African Court. It argues that in an effort to lead continental human rights adjudication from a one-tier system (comprised of only a Commission) to a two-tier system (comprising both a Commission and Court), the African Court Protocol's drafters left the door wide open for continental human rights adjudication to regress to the pre- African Court epoch. That is to say, pragmatically leaving continental human rights adjudication to only a working African Commission and an inaccessible African Court. By examining the two main barriers, this paper will prove that this current jurisdictional regime, as practised, leads to a ' $c u l-d e-s a c$ ' - a road only leading us back to where we have come from. However, Part V of this paper proposes a way out of this conundrum. It recommends an amendment to the 2020 Rules of Procedure of the African Commission on Human and Peoples' Rights (the 2020 Rules of the African Commission) to introduce a default referral procedure from the African Commission to the African Court in instances where a state is non-compliant to the Commission's recommendations or provisional orders.

The paper is divided into five parts. Part I is this introduction. Part II traces the history of the provision on direct access for individuals and NGOs from the first to the final draft of the Protocol and how the Article 34(6) declaration came to be. Part III reports on the current status of the Article 34(6) declaration by states and the surge in withdrawals from it. It makes the case that these withdrawals fundamentally assist the slow but almost sure formation of the cul-de-sac with respect to direct access to the African Court. Part IV illustrates the role of the African Commission in completing the cul-de-sac by its near-total refusal to refer cases to the African Court. It evaluates the initial concerns and hopes of the Commission's role at the time of its establishment, as juxtaposed with the realities of today. Part $\mathrm{V}$ makes a genuine attempt at proposing a way forward from this conundrum, and Part VI is the conclusion.

\section{A Historical Examination of the African Court Protocol's Provi- sion on Direct Access for Individuals and NGOs}

As early as 1961, during the Conference on the Rule of Law in Lagos, there were calls to establish an African court with human rights jurisdiction. ${ }^{41}$ However, this was not to happen until much later in 1998 when the OAU adopted the African Court Protocol, which came into force in $2004 .{ }^{42}$ This paper attributes

\footnotetext{
${ }^{41}$ Eno R, 'The jurisdiction of the African Court on Human and Peoples' Rights', 225.

42 Viljoen F, 'A human rights court for Africa, and Africans', 1.
}

Vol. 6:1 (2021) p. 110 
that delay to state sovereignty, which it will demonstrate that African states have guarded jealously from the very beginning when they formed the OAU.

The OAU Charter came into force in 1963, founding the OAU. At this stage, African states' prioritisation of sovereignty over judicial dispute resolution was so much that under the OAU Charter, the Assembly of Heads of State and Government was the body charged with resolving disputes. ${ }^{43}$ Even when the OAU adopted the Banjul Charter, it rejected the notion of a court, preferring instead a quasi-judicial commission. ${ }^{44}$ Some scholars also trace that at this point, African states were preoccupied with protecting their sovereignty and limiting the channels through which to hold them accountable on their human rights obligations. ${ }^{45}$ This pre-occupation was informed by the fact that they were newly independent and wanted to safeguard this sovereignty and the non-interference of their domestic affairs. ${ }^{46}$

When the African Commission was established, African states were reluctant to permit individuals and NGOs unfettered direct access to it. While the February 1988 Rules of Procedure of the Commission did not give this permission, ${ }^{47}$ in its Third Session in April the same year, the Commission set a bold precedent by allowing individual communications. ${ }^{48}$ This was codified in the 2010 Rules of Procedure of the African Commission on Human and Peoples' Rights (the 2010 Rules of the African Commission). ${ }^{49}$

Eventually, when African states commenced discussions on the establishment of the African Court, they expressed the same disinclination to acquiesce to unfettered direct access to it by individuals. ${ }^{50}$ Generally, they seemed to favour access to the African Court through the Commission rather than direct access to the Court by individuals and NGOs. ${ }^{51}$ This prioritisation is discussed in Part III of this paper.

\footnotetext{
Viljoen F, 'A human rights court for Africa, and Africans', 6.

44 Eno R, 'The jurisdiction of the African Court on Human and Peoples' Rights', 225.

45 Moyn S, The last utopia: Human rights in History, Harvard University Press, Cambridge 2012, 84-119; Hassan B J, The law of the African (Banjul) Charter on Human and Peoples' Rights (1988-2006), Trafford Publishing, Victoria BC, 2007, 22. See also Harrington J, 'The African Court on Human and Peoples', 319.

46 Bekker G, 'The African Court on Human and Peoples' Rights', 152 and 154.

47 Bekker G, 'The African Court on Human and Peoples' Rights', 157.

48 Bekker G, 'The African Court on Human and Peoples' Rights', 157.

49 Rule 93(1), Rules of Procedure on the African Commission on Human and Peoples' Rights (2010).

50 Bekker G, 'The African Court on Human and Peoples' Rights', 166-167.

51 Ssenyonjo M, 'Direct access to the African Court on Human and Peoples' Rights by individuals and non-governmental organisations', 26.
} 
During a brain-storming session organised by the International Commission of Jurists (ICJ) in Dakar in January 1993, the participants, experts selected by the ICJ, ${ }^{52}$ agreed that a Protocol to the Banjul Charter, should be used to establish a Court. ${ }^{53}$ The session resulted in the first attempt to write a draft Protocol establishing an African Court, dubbed the 'Vasak' Draft Protocol. Its first major amendment allowed direct access to individuals and NGOs upon its ratification, with varied opinions on the specific conditions for this access. ${ }^{54}$

In November 1993, the Fifth ICJ Workshop on NGO Participation in the African Commission tasked the ICJ to prepare an explanatory note to the 'Vasak' Draft, considering the participants' comments. ${ }^{55}$ The finalised draft, the ICJ Draft, provided direct access to individuals (without going through the Commission), but only on 'exceptional grounds'. Part of the prerequisites was compliance with Article 56 of the Banjul Charter, ${ }^{56}$ and exhausting local remedies. ${ }^{57}$

The African NGOs present mounted a firm and successful resistance to the suggestion that once the Court was created it would replace the Commission. They argued that this proposal would expunge the Commission's promotional activities and its other functions such as facilitating strong NGO participation. This contributed to the retention of the Commission as an organ with a complementary relationship to the Court. ${ }^{58}$

In September 1995, a Government Experts Meeting convened in Cape Town occasioned the adoption of the first official African Court Draft Protocol, the Cape Town Draft. ${ }^{59}$ The Cape Town Draft substantially resembled the ICJ Draft, whose provisions had been largely influenced by the statutes of the InterAmerican Court, the European Court of Human Rights (ECtHR), their rules, the Charter of the International Court of Justice and the Banjul Charter. ${ }^{60}$

Bekker further notes that, while purely aimed at getting states on board, this draft compromised on unfettered access of individuals by retaining that

52 Gutto S, ICJ workshops on NGO participation in the African Commission on Human and People's Rights 19911996: A critical evaluation, 1996, 62.

53 Wolfgang B, '14th session of the African Commission on Human and Peoples' Rights' 12(1) Netherlands Quarterly of Human Rights, 1994, 86.

54 Wolfgang B, '14th session of the African Commission on Human and Peoples' Rights', 86.

55 Bekker G, 'The African Court on Human and Peoples’ Rights', 161.

56 Bekker G, 'The African Court on Human and Peoples' Rights', 162.

57 Article 56, African charter on human and people's rights.

58 Gutto S, ICJ workshops on NGO participation in the African Commission on Human and People's Rights 1991 1996, 62.

59 Viljoen F, 'A human rights court for Africa, and Africans', 9.

60 Bekker G, The African Court on Human and Peoples' Rights', 164.

Vol. 6:1 (2021) p. 112 
it would only be possible on 'exceptional grounds' which were neither defined nor delimited. ${ }^{61}$ This access would be without first going through the African Commission. ${ }^{62}$ The only improvement made on jurisdiction was the removal of the mandatory prerequisites of Article 56 of the Banjul Charter. ${ }^{63}$ The NGOs present criticised this provision for being very subjective and potentially making the decision of what amounts to 'exceptional circumstances' a political one. ${ }^{64}$

In April 1997, during a Government Experts Meeting preceding the twenty first Session of the African Commission, a second draft, the Nouakchott Draft, was adopted by the nineteen states in attendance. ${ }^{65}$ The Nouakchott Draft allowed direct access to the African Court to individuals and NGOs with observer status at the African Commission, without first approaching the Commission, but only for urgent matters of systemic or mass human rights violations. ${ }^{66}$ After receiving comments from the African states, the delegates struck out the exceptional jurisdiction granting individuals direct access to the African Court upon ratification, ${ }^{67}$ and introduced the requirement that a state must first make an optional declaration allowing the African Court to receive cases directly filed by individuals. ${ }^{68}$

The final draft, the Addis Ababa Draft, endorsed by the OAU Assembly included the Article 34(6) declaration as the prerequisite for individuals and NGOs to directly access the African Court. ${ }^{69}$

It is clear that when the first draft was written, there had been an intention to allow individuals and NGOs unfettered access to the African Court. Even though it is difficult to evidence this from the travaux préparatoires (preparatory works on the creation of the African Court),$^{70}$ the subsequent and final drafts of the Protocol evidence a lack of political will to support this, and therefore, the need to exclude it in order for states to ratify the Protocol. Mutua agrees with Udombana and Bekker that from the outset, the inclusion of this restriction was

61 Bekker G, The African Court on Human and Peoples' Rights', 165.

62 Ssenyonjo M, 'Direct access to the African Court on Human and Peoples' Rights by individuals and non-governmental organisations', 26.

63 Bekker G, The African Court on Human and Peoples' Rights', 165.

64 Udombana J, 'Toward the African Court on Human and Peoples' Rights: Better late than never', 88.

65 Viljoen F, 'A human rights court for Africa, and Africans', 10.

${ }_{66}$ Udombana J, 'Toward the African Court on Human and Peoples' Rights: Better late than never', 88.

67 Bekker G, The African Court on Human and Peoples' Rights', 167-168.

68 Viljoen F, 'A Human Rights Court for Africa, and Africans', 10.

69 Viljoen F, 'A Human Rights Court for Africa, and Africans', 10-11.

70 Plagis Ariana M, Riemer L, 'From context to content of human rights', 17.

Vol. 6:1 (2021) p. 113 
an incentive for African states to ratify the Protocol. ${ }^{71}$ Without this compromise then, the adoption of the Protocol may have taken much longer than it did. The lack of political will to support unfettered direct access to the Court by individuals and NGOs is not new, but existed from the very beginning as this part has demonstrated. So far, only ten states have ever made the declaration, out of which four have already bowed out in quick succession. ${ }^{72}$ This faculty of the optional declaration has, therefore, directly led to one of the dual contributors to the cul-de-sac.

\section{Direct Access to the African Court through Article 5(3) of the Protocol: A Report on the Current Status of Article 34(6) Declarations and the Surge in Withdrawals}

This paper addresses two main impediments to the direct access to the African Court, one being that the few states that have made the Article 34(6) declaration have begun withdrawing from it swiftly. ${ }^{73}$ Of the fifty-five African Union (AU) members, thirty-one have ratified the Protocol, among whom only ten have ever made the Article 34(6) declaration. ${ }^{74}$ These are Benin, Burkina Faso, Côte d'Ivoire, Gambia, Ghana, Malawi, Mali, Rwanda, Tunisia and Tanzania. ${ }^{75}$ Within a period of just five years, four out of the ten have already withdrawn. Rwanda led the way in $2016,{ }^{76}$ opening the path for three more rapid withdrawals by Tanzania in 2019, ${ }^{77}$ and Benin and Côte d'Ivoire in $2020 .^{78}$ The claim of

71 Mutua M, 'The African Human Rights Court: A two-legged stool?’, 355; Udombana J, 'Toward the African Court on Human and Peoples' Rights: better late than never', 87.

72 - https://www.african-court.org/wpafc/declarations/ on 9 January 2020.

73 -https://www.african-court.org/en/index.php/basic-documents/declaration-featured-articles-2 on 16 July 2020.

74 -https://www.african-court.org/en/images/Basic\%20Documents/Ratification_and_Deposit_of_ the_Declaration_final-May-2020.pdf on 18 August 2020; - https://www.african-court.org/wpafc/ democratic-republic-of-congo-ratifies-the-protocol-on-the-establishment-of-the-african-court-onhuman-and-peoples-rights/ on 10 January 2020.

75 -https://www.ejiltalk.org/individual-and-ngo-access-to-the-african-court-on-human-and-peoplesrights-the-latest-blow-from-tanzania/\#: :text=Of $\% 20$ the $\% 20$ African $\% 20$ Court's $\% 2030$, cases $\% 20$ from $\% 20$ individuals $\% 20$ and $\% 20$ NGOs on 6 January 2020.

76 Booyzen Y, 'Report: Rwanda's withdrawal of its acceptance of direct individual access to the African Human Rights Court' Centre for Human Rights, 22 March 2016 - https://www.up.ac.za/faculty-oflaw/news/post_2254556-report-rwandas-withdrawal-of-its-acceptance-of-direct-individual-accessto-the-african-human-rights-court on 18 August 2020.

77 -https://www.african-court.org/en/images/Declarations/retrait/NV\%20to\%20MS\%20-\%20 Withdrawal\%20Tanzania_E.PDF on 31 July 2020.

78 -https://www.african-court.org/en/images/Declarations/retrait/Retrait $\% 20 \mathrm{du} \% 20$ benin.pdf on 31 July 2020. ; - https://www.african court.org/en/images/Declarations/retrait/retrait $\% 20$ withdrawal $\% 20$ Cote $\% 20$ d'ivoire.pdf on 31 July 2020.

Vol. 6:1 (2021) p. 114 
interference with sovereignty has been at the heart of these withdrawals. This section of the paper discusses the four states that have withdrawn their Article 34(6) declaration as well as their justifications.

Based on the African Court's statistics at the time of writing, it had received a total of three hundred and ten cases. Of these, individuals have filed two hundred and eighty-eight cases, NGOs twenty cases and the African Commission has only referred three cases to the African Court. ${ }^{79} \mathrm{~A}$ great majority of the cases filed by both individuals and NGOs in total have been against states which have made the Article 34(6) declaration. Before withdrawing, Rwanda had six cases filed against it, Tanzania one hundred and thirty-eight, Benin twenty-eight and Côte d'Ivoire eighteen. ${ }^{80}$

Of the remaining six countries, Mali has twenty-seven cases filed against it, Burkina Faso eight, Tunisia and Gambia five and Malawi and Ghana four cases each. ${ }^{81}$ This shows that individuals and NGOs from the states that made a declaration have been exercising their right to unfettered access to the court. It is worth noting that the countries that have maintained their declaration have relatively lower numbers of cases, with Mali as the exception.

Thus far, the African Court has finalised ninety-eight applications, which is thirty-two percent of the total number of applications submitted to it; two hundred and ten applications are pending. It has further given two hundred and thirty decisions for the cases. ${ }^{82}$ Given the statistics, it goes without saying that Article 34(6) of the African Court's Protocol is by far the most travelled road to directly accessing the African Court as opposed to the Commission's referral path.

\section{i. $\quad$ The nature of Article 34(6) declarations}

Article 34(6) of the Protocol takes the form of an optional declaration. ${ }^{83}$ Such declarations are facultative unilateral engagements which states are free to make or not to make. ${ }^{84} \mathrm{Du}$ Plessis and Stone say that this prerogative of

\footnotetext{
79 -https://en.african-court.org/index.php/cases on 22 August 2020.

80 -https://www.african-court.org/en/index.php/cases/2016-10-17-16-18-21\#finalised-cases on 31 July 2020.

81 -https://www.african-court.org/cpmt/statistic on 8 January 2021.

82 -https://www.african-court.org/cpmt/statistic\# on 7 January 2021.

83 Enabulele A, 'The problems of jurisdiction by optional declaration: Reflections on Articles 5(3) and 34(6) of the Protocol of the African Court on Human and Peoples' Rights' 24(2) Australian Journal of Human Rights, 2018, 231.

84 Military and Paramilitary Activities in and Against Nicaragua (Nicaragua v United States of America) Merits Judgement, ICJ Reports, 1986, 59.
} 
states emphasises the argument that human rights are at their behest. ${ }^{85}$ This underscores the place of state sovereignty with regards to the African Court Protocol and perhaps explains why only ten out of the thirty states that have ratified the African Court Protocol, have further made the declaration.

The African Court Protocol neither has provisions on the withdrawal from Article 34(6) declarations nor does it require states to give justifications for withdrawing, but as has been the trend, withdrawing states have cited their motivations for the disengagement. ${ }^{86}$ One effect of this would be that more states could withdraw without giving justifications, thus making unclear their motivation for withdrawing. The African Court, however, has pronounced itself on this question in Ingabire Victoire Umubonza $v$ Republic of Rwanda. ${ }^{87}$ It stated that despite arising from a treaty which is subject to the Vienna Convention on the Law of Treaties (VCLT), optional declarations in themselves are unilateral acts which are not subject to the VCLT, except only in analogy.

The general rule regarding withdrawals from treaties is that where a treaty contains no provision on withdrawal or denunciation, the VCLT applies. ${ }^{88}$ The African Court explained that for unilateral acts, state parties are free to commit themselves and retain the discretion to withdraw their commitments. ${ }^{89}$ The rider is that the withdrawal only becomes effective after a one-year transitional period after a state has issued its notice of withdrawal. ${ }^{90}$ It is based on this understanding that the four withdrawals are discussed.

\section{ii. An epoch of rapid withdrawals}

The analysis advanced here focuses on the four withdrawals. It primarily aims at establishing the common patterns underlying the withdrawals. It sets forth the justifications given by states by examining the language of their statements of withdrawal, statements by government officials on the withdrawals and addresses the doctrine of exhaustion of local remedies.

\footnotetext{
85 Du Plessis M d and Stone L, 'A court not found?' 541.

86 Adjolohoun S, 'A crisis of design and judicial practice? Curbing state disengagement from the African Court on Human and Peoples’ Rights’ 20(1) Africa Human Rights Law Journal, 2020, 5.

87 AfCHPR Corrigendum to the Ruling on Jurisdiction of 5 September 2016, ii.

88 Article 56 (1) (a), (b), Vienna Convention on the Law of Treaties, 23 May 1969, 1155 UNTS 331.

89 Ingabire Victoire Umuboza v Republic of Rwanda, AfCHPR Judgement on 3 June 2016 (Ruling on Jurisdiction), 58, 59.

90 Ingabire Victoire $v$ Rwanda, (Ruling on Jurisdiction) AfCHPR, 66.
}

Vol. 6:1 (2021) p. 116 


\section{a. Rwanda}

Rwanda made the Article 34(6) declaration in 2013 and issued its notice of withdrawal in $2016 .{ }^{91}$ At least six cases were instituted by individuals against Rwanda in that three-year duration, the most notable being Ingabire Victoire Umubonza $v$ Republic of Rwanda, ${ }^{92}$ whose proceedings coincided with Rwanda's withdrawal. A few days before the hearing of this case, Rwanda officially informed the AU Commission and the African Court of its withdrawal. ${ }^{93}$

Rwanda's justification for withdrawing was that it did not envisage that a genocide convict who was a fugitive of justice would ever seek and be granted an audience in the African Court through the optional declaration. ${ }^{94}$ Its justification was geared towards the notion that there are certain categories of persons that should not be allowed access to the African Court at all such as genocide convicts. ${ }^{95}$ Viljoen, on the other hand, observes that Rwanda's withdrawal may be tied to the fact that Rwanda did not foresee the filing of six politically sensitive cases by opponents of the government in a very short period after making the declaration. ${ }^{96}$ While Rwanda's withdrawal charted the path for more withdrawals, it helped settle the contentious questions on withdrawing from the African Court Protocol through the decision in Ingabire Victoire Umubonza v Republic of Rwanda. ${ }^{97}$

\section{b. Tanzania}

Tanzania made the Article 34(6) declaration in 2010 and withdrew in 2019.98 Tanzania's withdrawal came as a shock to the continent since the seat of the

91 Booyzen Y, 'Report: Rwanda's withdrawal of its acceptance of direct individual access to the African Human Rights Court' Centre for Human Rights, 22 March 2016 - https://www.up.ac.za/faculty-oflaw/news/post_2254556-report-rwandas-withdrawal-of-its-acceptance-of-direct-individual-accessto-the-african-human-rights-court on 18 August 2020.

92 Ingabire Victoire $v$ Rwanda, (Ruling on Jurisdiction) AfCHPR, 66.

93 Booyzen Y, 'Report: Rwanda's withdrawal of its acceptance of direct individual access to the African Human Rights Court' Centre for Human Rights, 22 March 2016 - https://www.up.ac.za/faculty-oflaw/news/post_2254556-report-rwandas-withdrawal-of-its-acceptance-of-direct-individual-accessto-the-african-human-rights-court on 18 August 2020.

94 - https://www.african-court.org/wpafc/wp-content/uploads/2020/10/Withdrawal-Rwanda.pdf on 29 January 2021.

95 Nyarko M and Jegede A 'Human rights developments in the African Union during 2016' 17(1) African Human Rights Law Journal, 2017, 303.

96 Viljoen F, 'Understanding and overcoming challenges in accessing the African Court on Human and People's Rights' 67(1) International and Comparative Law Quarterly, 2018, 4.

${ }_{97}$ Ingabire Victoire $v$ Rwanda, (Ruling on Jurisdiction) AfCHPR.

98 Amnesty International, 'Joint statement condemning Tanzania's withdrawal on the right of individuals access to the African court' AFR 56/1542/2019 -https://www.amnesty.org/download/ Documents/AFR5615422019ENGLISH.PDF on 18 august 2020. 
African Court is in Arusha. Tanzania alone accounts for thirty-three percent of the African Court's finalised cases (thirty-three of the seventy-six) and sixty-three percent of pending cases (one hundred and five of the one hundred and sixtyseven). ${ }^{99}$ This high number may have been inspired by the Court's geographical location which was advantageous to Tanzanians who could easily approach it to file claims.

At the making of the declaration, Tanzania made a reservation to the effect that direct access to the African Court would only be possible after local remedies have been exhausted and in compliance with Tanzania's Constitution. ${ }^{100}$ The ground for withdrawal adduced by Tanzania in its notice of withdrawal was that the declaration was implemented contrary to this reservation, however, giving no substantiated evidence for this. ${ }^{101}$

The withdrawal came right before the African Court's decision in Ally Rajab and others $v$ United Republic of Tanzania, ${ }^{102}$ in which it held that the mandatory death sentence in Tanzania's Penal Code was against the African Charter and constituted an arbitrary deprivation of the right to life. ${ }^{103}$ Commenting on the withdrawal, the Pretoria Centre for Human Rights (Pretoria CHR) expressed concern that it was not clear how the Court had violated Tanzania's caveat and that withdrawing on such vague grounds created a bad precedent for other states. ${ }^{104}$

It is evident that before the withdrawal, Tanzania was experiencing a litigation load, as it was the defendant in one hundred and thirty-eight cases. Additionally, there was the burden of honouring the Court's orders, which included pecuniary orders amounting to approximately one hundred and six thousand US dollars. ${ }^{105}$

99 Nicole de Silva, 'Individual and NGO access to the African Court on human and peoples' rights: The latest blow from Tanzania’ EJIL: Talk!, 16 December 2019 - https://www.ejiltalk.org/individualand-ngo-access-to-the-african-court-on-human-and-peoples-rights-the-latest-blow-from-tanzania/ on 21 August 2020.

100 Centre for Human Rights, 'Press statement: Centre for human rights expresses concern about Tanzania's withdrawal of access to the African court by individuals and NGOs' University of Pretoria, 5 December 2019 - https://www.chr.up.ac.za/press-statements/1916-press-statementcentre-for-human-rights-expresses-concern-about-tanzania-s-withdrawal-of-access-to-the-africancourt-by-individuals-and-ngos on 18 august 2020.

101 Centre for Human Rights, 'Press statement' Tanzania. See also Tanzania's notice of withdrawal of the declaration made under Article 34(6) of the Protocol on the African Court on Human and People's Rights, AfCHPR - http://www.african-court.org/en/images/Declarations/retrait/ NV\%20to\%20MS\%20-\%20Withdrawal\%20Tanzania_E.PDF on 18 August 2020.

102 AfCHPR Judgement of 28 November 2019, (Jurisdiction, Merits, Reparation).

103 Ally Rajab and others v Tanzania (Jurisdiction, Merits, Reparation) AfCHPR, 111.

104 Centre for Human Rights, 'Press statement' Tanzania.

105 Adjolohoun S, 'A crisis of design and judicial practice? Curbing state disengagement from the African Court on Human and Peoples' Rights' 1(20) Africa Human Rights Law Journal, 2020, 10.

Vol. 6:1 (2021) p. 118 
Lastly, some leading decisions touched on Tanzania's domestic criminal policy, indirectly reversed the rulings of its highest court and compensated persons who had been found guilty of crimes by national courts. ${ }^{106}$

\section{c. Benin}

Benin made its Article 34(6) declaration in 2016 and withdrew in April 2020. In its notice of withdrawal, it contends that the African Court exceeded its jurisdiction, resulting in the disruption of Benin's national legal order and led to judicial uncertainty, which has in turn affected its economic viability negatively. ${ }^{107}$ The state considered this as unwarranted interference by making reference to the African Court's recent rulings against Benin on two related cases; Ghaby Kodeih v Republic of Benin (Ghaby Kodeih I) and Ghaby Kodeih and Nabih Kodeih v Republic of Benin (Kodeih II). In both cases, the Court issued orders of provisional measures against Benin. ${ }^{108}$

In Ghaby Kodeih II, the Court issued provisional measures for the stay of the execution of a judgement issued by a national court in Benin. Benin condemned this claiming that such economic disputes could be resolved nationally by the Appeal Court at Cotonou and the Common Court of Justice and Arbitration (CCJA). It claimed that the CCJA is the court of last resort for such economic matters in Benin. ${ }^{109}$ Benin declared that the African Court's decision to rule on such a matter constituted blatant overstepping of its jurisdiction. ${ }^{110}$ The African Court, on the other hand, found that it had jurisdiction ratione materiae as the alleged violations were on the rights provided in the African Charter and not purely commercial transactions. ${ }^{111}$

106 Thomas v Tanzania, AfCHPR (Reparations) 4 July 2019; Abubakari $v$ Tanzania, AfCHPR (Reparations) 4 July 2019 and Wilfred Onyango Nganyi and others v Tanzania, AfCHPR (Reparations) 4 July 2019.

107 University of Pretoria Centre for Human Rights, 'Press statement: Centre for Human Rights expresses concern about the withdrawal of direct individual access of individuals to the African Court by Benin and Cote d'Ivoire' Centre for Human Rights, 5 May 2020 - https://www.chr. up.ac.za/images/centrenews/2020/Centre_for_Human_Rights_expresses_concern_about_the_ withdrawal_of_direct_individual_access_to_the_African_Court_by_Benin_and_Cote_dIvoire.pdf on 13 August 2020.

108 Ghaby Kodeih v Republic of Benin (Order for Provisional Measures), AfCHPR, Application No. 006/2020, 28 February 2020.

109 University of Pretoria Centre for Human Rights, 'Press Statement: Centre for Human Rights expresses concern about the withdrawal of direct individual access of individuals to the African Court by Benin and Cote d'Ivoire' Centre for Human Rights, 5 May 2020 - https://www.chr. up.ac.za/images/centrenews/2020/Centre_for_Human_Rights_expresses_concern_about_the_ withdrawal_of_direct_individual_access_to_the_African_Court_by_Benin_and_Cote_dIvoire.pdf on 13 August 2020.

110 Press Releases, "Withdrawal of Benin from the ACHPR: Statement by the minister of justice and legislation' Government of the Republic of Benin, 28 April 2020 - https://www.gouv.bj/ actualite/635/retrait-benin-cadhp---declaration-ministre-justice-legislation/ on 18 August 2020.

111 Alleged violations were on Articles 7.1 (a), 7.1 (b) and 14, African Charter on Human and Peoples' Rights.

Vol. 6:1 (2021) p. 119 
Commenting on Benin's withdrawal, the Pretoria CHR stated that another case, Sébastien Germain Ajavon v Republic of Beninmay have played a role in it. ${ }^{112}$ The applicant, a strong contender in the 2016 presidential election, was charged and convicted by a Beninese court for international drug trafficking but denied the charge and sought asylum in France. ${ }^{113}$ The conviction ruled him out of vying for the 2021 presidential elections. He sought reparation for violation of his rights to a fair trial in the Beninese criminal justice system. The African Court upheld his claim and issued pecuniary orders in his favour. ${ }^{114}$

It may not be surprising that the withdrawal came a day after the African Court ordered the suspension of the 17 May 2020 communal elections in Benin, still upon the application of Sébastien Germain who claimed that the elections would cause him irreparable harm. ${ }^{115}$ This appears to be an instance in which Benin considered such an order to be interfering with its national matters.

The Beninese government, however, maintained that the withdrawal was due to 'repeated slippages' and that the African Court's annulment of the elections had very little to do with it. ${ }^{116}$ The government spokesperson nonetheless commented that the Court was overstepping its jurisdiction as elections are a national matter and evoked state sovereignty. ${ }^{117} \mathrm{He}$ accused the Court of pretending to preserve an individual's rights while jeopardising the interests of an entire nation to hold elections. Thus, the annulment disregarded Benin's national interests. ${ }^{118}$

It is not in doubt that the applicants in these cases correctly exercised their right to direct access to the African Court based on Benin's declaration permitting

112 Sébastien Germain Ajavon v Republic of Benin (Judgment: Reparation), AfCHPR, Application No. 013/2017, 28 November 2019; Centre for Human Rights, 'Press Statement: Centre for Human Rights expresses concern about the withdrawal of direct individual access of individuals to the African Court by Benin and Cote d'Ivoire'.

113 Ajavon v Benin, AfCHPR, 3-4.

114 Ajavon v Benin, AfCHPR, 36-41.

115 Olivier Ribouis, 'Communales 2020: Ajavon Obtains the Suspension of Election to the African Court' Banouto, 17 April 2020 - -https://archives.banouto.info/article/politique/20200417communale-2020-ajavon-obtient-la-suspension-de-l-lection--la-cour-africaine/ on 9 February 2021.

116 Hervé H, 'On the question of whether the African Court exceeded its jurisdiction, Benin's withdrawal from the African court: Minister Alain Orounla's clarifications’ Banouto, 23 April 2020 - https://www.banouto.info/article/POLITIQUE/20200423-retrait-du-bnin-de-la-cour-africaineles-clarifications-du-ministre-alain-orounla/ on 15 August 2020.

117 Hervé Y, 'Ajavon's complaint against the Communals: 'The government maintains the election (Alain Orounla)’ Banouto, 20 April 2020 - https://www.banouto.info/article/politique/20200420plainte-d-ajavon-contre-les-communales-le-gouvernement-maintient-l-lection-alain-orounla/ on 15 August 2020.

118 Cochimau S., 'ACHPR: Benin gives reasons for withdrawing its declaration' Benin Web Tv, 23 April 2020 - https://beninwebtv.com/2020/04/cadhp-le-benin-donne-les-raisons-du-retrait-de-sadeclaration/ on 15 August 2020.

Vol. 6:1 (2021) p. 120 
this. However, Benin's withdrawal clearly seems to be due to the numerous orders issued against it which in its perspective, like Rwanda and Tanzania, threaten its sovereignty and additionally, its economic interests.

\section{d. Côte d'Ivoire}

This is the latest country to withdraw its declaration in April 2020 after depositing it in $2013 .{ }^{119}$ The notice of withdrawal did not include any justification for disengaging. The Ivorian Minister of Communication and Media later stated that the withdrawal was a result of serious and intolerable actions by the African Court and that the actions of the Court constituted infringement of sovereignty, upset the national legal order and undermined the rule of law. ${ }^{120}$ The withdrawal came just six days after the African Court issued an order for provisional measures in Guillaume Kigbafori Soro and others v Republic of Côte D'Ivoire, ${ }^{121}$ suspending an arrest warrant issued the same month by Côte d'Ivoire against Soro, a former Prime Minister and rebel leader who had declared an interest in running in the 2020 presidential elections. ${ }^{122}$ With regard to sovereignty, the decision appeared to disturb the state's politics, undermine the state's rule of law and to override the national courts.

Based on reports by the Coalition of Ivorian Defenders of Human Rights and CIVICUS, the country is regrettably still marred by human rights violations, especially on the right to freedom of association, peaceful assembly and expression. ${ }^{123}$

\section{iii. Conclusion}

A clear pattern that appears is that the countries that have withdrawn their Article 34(6) declaration are those that have had the highest number of cases filed against them in the Court by individuals and NGOs. Mali, however, still maintains its declaration despite having a considerably higher number of cases in the Court than the other five that have so far maintained their declarations as well.

\footnotetext{
119 -https://www.african-court.org/en/index.php/basic-documents/declaration-featured-articles-2 on 31 July 2020.

120 - http://www.gouv.ci/ actualite-article.php?recordID=11086 on 12 August 2020.

121 Guillaume Kigbafori Soro and others v Republic of Côte D'Ivoire (Order for provisional measures), AfCHPR, Application No. 012/2020, 22 April 2020.

122 Tetevi D and Ezechiel A, 'Another one bites the dust: Côte D'Ivoire to end individual and NGO Access to the African Court' EJIL: Talk, May 192020 - https://www.ejiltalk.org/another-one-bitesthe-dust-cote-divoire-to-end-individual-and-ngo-access-to-the-african-court/ on 12 August 2020.

123 CIVICUS and Coalition Ivoirienne des Défenseurs des droits Humains, Republic of Côte d'Ivoire, joint submission to the UN universal periodic review: 33 rd Session of the UPR Working Group', 4 October 2018.
} 
The four withdrawals deny individuals and NGOs direct access to a judicial platform for seeking redress for violations of their rights and to hold the states accountable for their human rights commitments and obligations beyond the national level, especially after complainants have exhausted local remedies. The overarching justifications for these withdrawals by all four states are both expressly and implicitly based on concerns about the African Court's interference with their national affairs and the national judicial systems, which speak to concerns about sovereignty. The four withdrawals, although valid, have set a precedent for further withdrawals from the remaining six countries, a situation that plays a role in ultimately leading direct access to the African Court by individuals and NGOs closer to the cul-de-sac.

This situation presents a delicate balance for the African Court. On the one hand, the court could consider exercising its authority and admit cases presented to it that touch on highly political matters. This way, it will risk having a state withdrawing if it issues an order or decision that upsets the state. Should the state withdraw, then other individuals and NGOs will have their direct access revoked even for cases that are not sensitive to the states.

On the other hand, the court could learn from this pattern of withdrawals and take a hands-off approach whenever presented with highly political cases. However, this would not be beneficial to complainants who have exhausted local remedies and are left with the African Court as the judicial altar of refuge. It then becomes more of a question of how to balance the interests of promoting justice and executing its mandate despite the delicate background circumstances of some of the cases submitted to it. This discussion is elaborated in the recommendations section under Part V of this paper.

\section{The African Commission as an Avenue for Direct Access to the Afri- can Court}

The African Court Protocol grants locus standi to the African Commission to refer cases to the Court against any state, including those that have not made the Article 34(6) declaration. ${ }^{124}$ This serves to operationalise the complementarity relationship between the African Commission and African Court as envisioned in Article 2 of the African Court Protocol. ${ }^{125}$ These communications may include

\footnotetext{
124 Article 5(1)(a), Protocol to the African Charter on Human and Peoples' Rights on the Establishment of An African Court on Human and Peoples' Rights.

125 Article 2, Protocol to the African Charter on Human and Peoples' Rights on the Establishment of an African Court of Human and People's Rights; Article 30, African Charter on Human and Peoples' Rights.
}

Vol. 6:1 (2021) p. 122 
those filed to the African Commission by non-state actors such as NGOs and individuals. Commenting on the role of the African Commission, Frans Viljoen was confident that it would be the main means of access to the African Court through the faculty of referrals. ${ }^{126}$ Robert Wundeh Eno suggested that an effective Commission would close the gap of the potential failure of countries to make the Article 34(6) declaration, ${ }^{127}$ while Rachel Murray agreed with Julia Harrington in observing that:

'Embedded in this system is the necessity that the Commission work actively and effectively, or else the stream of potential cases that might eventually come before the Court will be choked off at source'. ${ }^{128}$

Perhaps this was informed by the envisioned complementary relationship between the two institutions. ${ }^{129}$ More so, due to the Protocol's firm conviction that establishing the African Court to reinforce and complement the African Commission was necessary to achieve the African Charter's objectives. ${ }^{130}$ Notably, Minority Rights Group International (MRG), a leading human rights NGO, notes that only individuals and NGOs from the countries that have made the Article 34(6) declaration will be able to make use of the African Court directly, while those from the remaining African states will rely on the African Commission to file cases on their behalf. ${ }^{131}$

Further, some researchers were optimistic that the adoption of the 2010 Rules would mean that the African Commission would refer a substantial number of cases to the African Court. ${ }^{132}$ This is due to the fairly elaborate grounds under which the African Commission may refer cases to the Court under Rule $118 .{ }^{133}$ Contrary to that, in the ten years that the 2010 Rules of the African Commission have been in operation, this optimism has been confounded by the fact that the African Commission only made three referrals. The African Commission

\footnotetext{
126 Viljoen F, 'A human rights court for Africa, and Africans', 23.

127 Eno R, 'The jurisdiction of the African Court on Human and Peoples' Rights', 231.

128 Murray R, 'A comparison between the African and European Courts of Human Rights' 2(2) African Human Rights Law Journal, 2002, 202, Harrington J, 'The African Court on Human and Peoples', 322.

129 Article 2, Protocol to the African Charter on Human and Peoples' Rights on the Establishment of an African Court on Human and Peoples' Rights.

130 Preamble, Protocol to the African Charter on Human and Peoples' Rights on the Establishment of an African Court on Human and Peoples' Rights.

131 Minority Rights Group International, African Court on Human and Peoples' Rights: Ten years on and still no justice, September 2008, 20.

132 Löffelmann M, 'Protection of human rights in theory and reality: The case of the African Court on Human and Peoples' Rights' 85(1/2) Die Friedens-Warte, 2010, 170.

133 Rule 118, Rules of Procedure on the African Commission on Human and Peoples' Rights (2010).
} 
recently adopted new rules of procedure, the 2020 Rules, operational from 2 June $2020 .{ }^{134}$ The 2020 Rules provide that the only instance in which the Commission may choose to refer a communication to the African Court is before the Commission has decided on the admissibility of the communication and only against a state that has ratified the African Court Protocol. ${ }^{135}$ The new Rules thus significantly claw back the progress that was made by the 2010 Rules of the African Commission with regard to referral of cases to the African Court by being less specific and reducing the grounds for referral to one. The review process of the 2010 Rules was initiated by the African Commission's Resolution 328 of 2016. ${ }^{136}$ The African Commission has noted that Rule 130 of the 2020 Rules sets out a simpler approach to enable the African Commission to refer the cases to the African Court. ${ }^{137}$ However, this presents the problem of ambiguity as it is not clear whether the African Commission would be able to refer cases at a later stage of its examination of the communications or even under the grounds previously contained in the 2010 Rules.

\section{i. Referral of cases by the African Commission to the African Court}

The African Commission is currently operating under the 2020 Rules. The now defunct 2010 Rules, which have been in use for ten years, provide grounds for the Commission to refer communications to the African Court. The Commission wielded the prerogative of determining which cases it refers to the Court by virtue of the use of 'may' in Rule 118 of its 2010 Rules. ${ }^{138}$ Further, its decisions are made through consensus of all Commissioners and, if not, by voting. ${ }^{139}$

The 2010 Rules stipulated four grounds for referral. Firstly, where the Commission had issued a decision against a state but the state was noncompliant or unwilling to effect its recommendations within one hundred and eighty days, ${ }^{140}$ it had the authority to refer the case to the Court or not to do so. Secondly, where it has issued a request for provisional measures in cases where the victims would suffer irreparable harm but the State was noncompliant in effecting it. ${ }^{141}$

\footnotetext{
134 - https://www.achpr.org/pressrelease/detail?id=518 on 29 January 2021.

135 Rule 130, Rules of Procedure on the African Commission on Human and Peoples' Rights (2020).

136 - https://www.achpr.org/pressrelease/detail?id=518 on 9 February 2021.

137 - https://www.achpr.org/pressrelease/detail?id=518 on 9 February 2021.

138 Rule 118, Rules of Procedure on the African Commission on Human and Peoples' Rights (2010).

139 Rule 51 (1), Rules of Procedure on the African Commission on Human and Peoples' Rights (2010).

140 Rule 118 (1), Rules of Procedure on the African Commission on Human and Peoples' Rights (2010).

141 Rule 118 (2), Rules of Procedure on the African Commission on Human and Peoples' Rights (2010).
}

Vol. 6:1 (2021) p. 124 
Thirdly, where it was informed of allegations of serious or massive human rights violations by a state, as listed in Article 58 of the Banjul Charter. ${ }^{142}$ Lastly, it could do so at any stage of examining a communication. ${ }^{143}$ The Commission would then represent the complainants once it referred the case to the African Court. ${ }^{144}$

Under the African Court's 2010 Rules, access to justice was highlighted by allowing the African Court to listen to the African Commission as the applicant as well as the original complainants, that is, individuals and NGOs who submitted the communication to the African Commission if it deemed this necessary. ${ }^{145}$ This position is retained in the African Court's 2020 Rules. ${ }^{146}$ However, under the 2020 Rules of the Commission, it cannot refer cases to the African Court under the four grounds. This bars access to justice for individuals and NGOs especially when the Commission has made a decision or a request for provisional measures which the state fails to implement, in which case, the Commission will lack the authority to approach the Court.

Since the African Court's coming into operation, the African Commission has held thirty-one Ordinary Sessions and twenty-six Extraordinary Sessions. ${ }^{147}$ It has only referred three cases to the Court out of all the communications it has approved for consideration during these sessions. ${ }^{148}$

Several reasons for non-referral have been advanced. Firstly, most states which failed to comply with the African Commission's recommendations have not yet ratified the African Court Protocol. ${ }^{149}$ Secondly, Viljoen advances the argument that referrals would undergo de novo consideration, meaning that the African Court would undergo full consideration of the case including its admissibility and merits. ${ }^{150}$ Cases that the African Commission had determined on their merits under Rule 118(1) of its 2010 Rules, where there was noncompliance,

\footnotetext{
142 Rule 118 (3) and 84(2), Rules of Procedure on the African Commission on Human and Peoples' Rights (2010).

143 Rule 118 (4), Rules of Procedure on the African Commission on Human and Peoples' Rights (2010).

144 Rule 120 and 121, Rules of Procedure on the African Commission on Human and Peoples' Rights (2010); Rule 29 (3), Rules of the African Court on Human and Peoples' Rights (2010).

145 Rule 29 (3), Rules of the African Court on Human and Peoples' Rights (2010).

146 Rule 36 (3), Rules of the African Court on Human and Peoples' Rights (2020.

147 -https://www.achpr.org/sessions on 17 July 2020.

148 -https://en.african-court.org/index.php/cases/2016-10-17-16-18-21 on 17 July 2020.

149 Ssenyonjo M, 'Responding to human rights violations in Africa assessing the role of the African Commission and Court on Human and Peoples' Rights (1987-2018)' 7 International Human Rights Law Review, 2018, 35; - https://www.african-court.org/wpafc/basic-information/\#ratification on 10 January 2020.

150 Vijoen F, 'Understanding and overcoming challenges in accessing the African Court on Human and Peoples’ Rights' 67(1) International and Comparative Law Quarterly, 2018, 85.
} 
would be at risk of the African Court reaching different findings from those of the African Commission after reconsideration of the facts. This would delegitimise the African Commission to some extent, despite it having established its own jurisprudence. ${ }^{151}$

Further, there would also be difficulty in establishing actual noncompliance with requests for provisional measures or recommendations issued to respondent states. ${ }^{152}$ This could be the reason for the delay in making referrals to the African Court since compliance is a matter of political goodwill and may be difficult to quantify exhaustively as it may take the form of a series of processes in the respondent state. ${ }^{153}$ This in turn speaks to the African Commission's discretion under its 2010 Rules in deciding whether or not to refer such cases to the African Court. ${ }^{154}$

The next part proceeds to examine the circumstances surrounding the three cases the African Commission has referred to the African Court, in light of the Commission's wide discretion on referrals to the Court. ${ }^{155}$

\section{a. African Commission on Human and Peoples' Rights v Great Social- ist People's Libyan Arab Jamahiriya}

This case concerning the dire human rights violations by Libya's government was tabled to the African Commission on 29 February 2011. ${ }^{156}$ Libyan security forces had indiscriminately used lethal force against peaceful demonstrators on 19 February. ${ }^{157}$ The African Commission considered this a case of serious and massive human rights violations, and referred it to the Court by 16 March. ${ }^{158}$ The African Court asserted that there was need to avert irreparable harm to persons,

\footnotetext{
151 Vijoen F, 'Understanding and overcoming challenges in accessing the African Court', 85.

152 Vijoen F, 'Understanding and overcoming challenges in accessing the African Court', 86.

153 Vijoen F, 'Understanding and overcoming challenges in accessing the African Court', 86.

154 Rule 118 (2), Rules of Procedure on the African Commission on Human and Peoples' Rights (2010).

155 See African Commission on Human and Peoples' Rights v Great Socialist People's Libyan Arab Jamabiriya (Order for provisional measures), AfCHPR, Application No. 004/2011, 25 March 2011. See also, African Commission on Human and Peoples' Rights $v$ Republic of Kenya (Judgment), AfCHPR, Application No. 006/2012, 26 May 2017 and African Commission on Human and Peoples' Rights v Libya (Order of provisional measures), AfCHPR, Application No. 002/2013, 3 June 2016.

156 Polymenopoulou E, 'African Court on Human and Peoples' Rights, African Commission on Human and Peoples’ Rights v Great Socialist People's Libyan Arab Jamahiriya', Order for provisional measures on 25 March 2011' 61(3) The International and Comparative Law Quarterly, 2012, 769.

157 African Commission on Human and Peoples' Rights v Great Socialist People's Libyan Arab Jamabiriya, AfCHPR, 3 and 5 .

158 African Commission on Human and Peoples' Rights v Great Socialist People's Libyan Arab Jamabiriya, AfCHPR, 2.
}

Vol. 6:1 (2021) p. 126 
159 and therefore, on 25 March ordered Libya to halt all actions that led to the loss of lives and physical abuse of persons. ${ }^{160}$

This case was, however, and disappointingly so, struck out due to the applicant's failure to file its reply within the time extension allowed by the African Court and failure to respond to the respondent's request to drop the case despite being served. This request was premised on the fact that the respondent government was no longer in existence. ${ }^{161}$

This first referral appeared to set a good precedent and showed much promise for subsequent cases given the swiftness with which it was referred to the African Court, shedding a ray of hope that the African Commission was ready to intervene swiftly and involve the Court to intercept human rights violations. If this set path were to be followed, then individuals and NGOs would be assured an audience with the judicial

body through the quasi-judicial body to present their grievances on human rights violations. For instance, in cases where a state has failed to comply with the Commission's requests for provisional measures, then they could get a binding order for provisional measures from the Court. ${ }^{162}$ However, this was only to be short-lived.

\section{b. The African Commission on Human and Peoples' Rights v Republic of Kenya}

This was the second referral made by the African Commission. The communication was filed to the African Commission in November 2009 concerning an eviction notice that the Kenyan government had issued against the Ogiek community. ${ }^{163}$ The African Commission concluded that if the order was carried out, it could cause irreparable harm to the community. It thus issued a request for provisional measures during the same November, asking Kenya to desist from actions that might cause irreparable prejudice to members of the Ogiek community. The ground for referral cited by the commission was that this was a case of serious and massive violations of human rights, including the right to life

\footnotetext{
Article 27(2), Protocol to the African Charter on Human and Peoples' Rights on the Establishment of an African Court of Human and People's Rights.

160 African Commission on Human and Peoples' Rights v Great Socialist People's Libyan Arab Jamabiriya, AfCHPR, 4 and 7.

161 African Commission on Human and Peoples' Rights v Great Socialist People's Libyan Arab Jamabirija, AfCHPR, 5.

162 Ssenyonjo M, 'The African Commission and Court on Human and Peoples' Rights' in Oberleitner G (ed) International Human Rights Institutions, Tribunals, and Courts, Springer, Berlin, 2018, 505.

163 African Commission on Human and Peoples' Rights v Republic of Kenya, AfCHPR, 2.
} 
and, in addition, the noncompliance by Kenya with the provisional measures. ${ }^{164}$ Kenya, however, did not respond to the allegations of noncompliance. ${ }^{165}$

The 2010 Rules of the Commission, however, did not provide a timeframe within which it could refer a communication based on the ground of noncompliance with a request for provisional measures issued against a respondent state. It therefore only referred this case to the African Court three years later, in July 2012. ${ }^{166}$ This is unlike the first ground of referral in which the African Commission could refer the case after six months of a state's noncompliance with its recommendations. ${ }^{167}$ This reluctance by the African Commission was a departure from the swift and robust body it had been during its first referral. Even more worrying, the African Commission had considered the nature of the violations against the Ogiek to be serious and with the potential to cause irreparable harm to them. ${ }^{168}$ The African Commission provided no reasons for the delay.

The African Court gave its decision on the merits in favour of the applicant in May 2017 which has had far-reaching positive impacts. Firstly, it put an end to decades of frustrated litigation by the Ogiek on their rights in Kenyan courts. ${ }^{169}$ Secondly, it joined Kenya's 2010 Constitution in recognising indigenous groups in the country, as they had remained unrecognised by the government before then. ${ }^{170}$ Thirdly, by urging Kenya to cease violating indigenous groups' rights, it added to the pressure from various actors in the international community such as the African Commission Working Group on Indigenous Populations/Communities and the African Commission. ${ }^{171}$ Lastly, it prompted the Kenyan government to take positive steps towards guaranteeing Ogiek's rights. Kenya gazetted a task force in 2017 and another in 2018 to facilitate the implementation of the Court's decision. Ogiek Peoples' Development Programme acknowledges that the little progress by the task force represents an improvement in the quest of the enjoyment of human rights by marginalised and indigenous communities in Kenya. ${ }^{172}$

\footnotetext{
164 African Commission on Human and Peoples' Rights v Republic of Kenya, AfCHPR, 2.

165 African Commission on Human and Peoples' Rights v Republic of Kenya, AfCHPR, 2.

166 African Commission on Human and Peoples' Rights v Republic of Kenya, AfCHPR, 2.

167 Rule 118 (1), Rules of Procedure on the African Commission on Human and Peoples' Rights (2010).

168 African Commission on Human and Peoples' Rights $v$ Republic of Kenya, AfCHPR, 2.

169 African Commission on Human and Peoples' Rights v Republic of Kenya, AfCHPR, 27.

170 Minority Rights Group International, Kenya at 50: Unrealized rights of minorities and indigenous peoples, 8 March 2012, 3.

171 African Commission on Human and Peoples' Rights and International Work Group for Indigenous Affairs, Report of the African Commission Working Group on Indigenous Populations/Communities, 2012, 19. African Commission on Human and Peoples' Rights $v$ Republic of Kenya, AfCHPR.

172 Minority Rights Group International, 'Two years on, Kenya has yet to implement judgment in Ogiek case’ Minority Rights Group International, 5 June 2019 - https://minorityrights.org/2019/06/05/
}

Vol. 6:1 (2021) p. 128 


\section{c. The African Commission on Human and Peoples' Rights v Libya}

So far, this is the last case the African Commission has referred to the African Court. The African Commission received a complaint in April 2012 alleging that the Libyan government had detained Saif Al- Islam Gaddafi in an unknown detention facility, that he had neither been charged with any offence nor presented in court and that there was an 'imminent trial' in which he could face a death sentence. ${ }^{173} \mathrm{It}$ issued a request for provisional measures in the same month against Libya to prevent irreparable harm but Libya did not respond or comply. ${ }^{174}$ It is on this basis that the African Commission made the referral, nine months later in January 2013. ${ }^{175}$ The African Court ordered Libya to cease the violations of his rights. ${ }^{176}$

The decision marked three significant milestones. It was the first referral made by the African Commission to the Court that was decided on its merits. It was also the first case where the Court decided in default; that is, it decided on a case even when the respondent state refused or failed to participate in the proceedings as Libya did in this case. Lastly, it affirmed that states' human rights obligations are not dispensed with in cases where human rights are violated in their territory by a group not controlled by the government, and therefore, states cannot simply say that they could not do anything about the violations. ${ }^{177}$

\section{ii. Instance in which the Commission should have referred cases to the Court but failed to make the referral}

As discussed elsewhere in the paper, the 2010 Rules of the Commission gave four grounds under which it could refer cases to the Court, two of which are when a state has failed to comply with its recommendations or request for provisional measures. ${ }^{178}$ State parties have largely failed to comply on both grounds. Allwell Uwazuruike noted that, as of 2018, the rate of compliance of the Commission's decisions was at just fifteen percent. ${ }^{179}$ The African Commission

two-years-on-kenya-has-yet-to-implement-judgment-in-ogiek-case-mrg-statement/ on 18 July 2020.

173 The African Commission on Human and Peoples' Rights v Libya, AfCHPR, 2-3.

174 The African Commission on Human and Peoples' Rights v Libya, AfCHPR, 3.

175 The African Commission on Human and Peoples' Rights v Libya, AfCHPR, 2-4.

176 The African Commission on Human and Peoples' Rights v Libya, AfCHPR, 6.

177 Windridge O, 'In default: African Commission on Human and Peoples' Rights v Libya' 18(2) African Human Rights Law Journal, 2018, 759, 774-775.

178 Rule 118), Rules of Procedure on the African Commission on Human and Peoples' Rights (2010).

179 Uwazuruike A, 'A proposal for the effective implementation of the protective mandate of the African Commission on Human and Peoples' Rights' 11 African Journal of Legal Studies, 2018, 182, 183. 
itself through its activity reports has admitted a relatively low rate of compliance with its requests for provisional measures and recommendations. ${ }^{180}$ While such noncompliance gives the leeway to the African Commission to make referrals to the Court, it has remained adamant to do so, effectively denying individuals and NGOs access to justice through the African Court.

One such instance where it elected not to refer a case to the Court is in Centre for Minority Rights Development (Kenya) and Minority Rights Group International on behalf of Endorois Welfare Council v Kenya (Endorois Case). ${ }^{181}$ Despite the Commission issuing the decision in the Endorois Case in 2010 and concluding a resolution in 2013 calling on the Republic of Kenya to implement the Endorois Decision, it still had not made use of the faculty of referral under Article 118(1) of its 2010 Rules. ${ }^{182}$

So far, the African Commission has proven that it is not a reliable avenue to the direct access granted to individuals and NGOs by the Article 34(6) declaration. It has almost entirely failed to exploit the opportunity of direct access as granted by the Protocol to refer to the African Court cases of human rights violations against countries that have not made the declaration but have ratified the African Court Protocol. And even in the three cases where it has done this, it has shown inconsistency in terms of how prompt it makes a referral. With this inconsistency, human rights violations victims who look to the African Commission as an avenue to reach the judicial body are not assured of this outcome, hindering their access to justice. This trend brings to light the fact that in the absence of the optional declarations by states, individuals and NGOs cannot achieve meaningful access to the African Court. To this extent, the African Commission is the second side of the coin of the main contributors to the cul-de-sac.

\section{iii. Comparative study with the European and Inter-American human rights systems}

As mentioned in Part II of this paper, the writers of the Cape Town Draft made reference to the American and European regional human rights system. ${ }^{183}$

\footnotetext{
180 See African Commission on Human and Peoples Rights, 47th Activity Report, 2019, 11; African Commission on Human and People's Rights, 45th Activity Report, 2018, 13; African Commission on Human and People's Rights, 43rd Activity Report, 2017, 8; African Commission on Human and People's Rights, 41st Activity Report, 2016, 11.

181 Centre for Minority Rights Development (Kenya) and Minority Rights Group International on behalf of Endorois Welfare Council v Kenya, ACmHPR Comm. 276/2003.

182 African Commission Resolution Calling on the Republic of Kenya to Implement the Endorois Decision - ACHPR/Res.257(LIV)2013.

183 Bekker G, 'The African Court on Human and Peoples’ Rights', 164-165.
}

Vol. 6:1 (2021) p. 130 
The European human rights system was initially a two-pronged system, with the European Commission on Human Rights and the Court of Human Rights. ${ }^{184}$ Individuals and NGOs could only approach the Court of Human Rights through the European Commission which would consider it and refer the case to the Court of Human Rights. ${ }^{185}$ Protocol 9 to the European Convention allowed direct applications to the European Court from any individual, NGOs and group of persons claiming a violation of human rights whose petition had gone through the European Commission with failure to secure a friendly settlement. ${ }^{186}$ A three-judge ad hoc panel of the Court determines admissibility of the case. ${ }^{187}$

Protocol 11 to the European Convention on Human Rights then amalgamated the European Commission and Court of Human Rights into one body, the permanent ECtHR. ${ }^{188}$ This had the effect of enabling individuals and NGOs to access the ECtHR directly. ${ }^{189}$ In light of the increased number of cases and growing membership of the Council of Europe, this was aimed at maintaining and improving efficiency in the protection of human rights. ${ }^{190}$ From 1954, up until 1988, the European Commission had only referred a maximum of twenty-five cases a year to the Court of Human Rights, and ninety-five a year from then on until 1993. This is juxtaposed by the fact that it had a total of two thousand six hundred and seventy-two pending cases as of January 1994. ${ }^{191}$

This figure was projected to soar and has proven to be true as the ECtHR had received on average between eighteen thousand cases in 1998 and between thirty thousand cases and fifty thousand cases from 2000 to 2006 annually. ${ }^{192}$ The number of cases submitted to the ECtHR from 2010 to 2020 ranged between

184 Bekker G, 'The African Court on Human and Peoples' Rights', 152

185 Bernhardt R, 'Reform of the Control Machinery under the European Convention on Human Rights: Protocol No. 11' 89(1) The American Journal of International Law, 1995.

186 Article 48, Protocol No. 9 to the Convention for the Protection of Human Rights and Fundamental Freedoms, 1 November 1994, ETS No. 140

187 Cerna, C, 'Introductory note to the new rules of the Inter-American Commission on Human and Peoples Rights' Inter-American Court on Human Rights, 2001 - https://www.corteidh.or.cr/ tablas/r31628.pdf on 28 January 2021.

188 Protocol No. 11 to the Convention for the Protection of Human Rights and Fundamental Freedoms, restructuring the control machinery established thereby, 11 May 1994, ETS No.155.

189 Protocol No. 11 to the Convention for the Protection of Human Rights and Fundamental Freedoms, restructuring the control machinery established thereby, 11 May 1994, ETS No.155.

190 Preamble, Protocol No. 11 to the Convention for the Protection of Human Rights and Fundamental Freedoms, restructuring the control machinery established thereby.

191 Council of Europe, Explanatory report to protocol No. 11 to the Convention for the protection of Human Rights and fundamental freedoms, restructuring the control machinery established thereby, 1994, para 21 - https://rm.coe.int/16800cb5e9 on 3 August 2020.

192 European Court of Human Rights analysis of statistics, 2006, 5 - https://www.echr.coe.int/ Documents/Stats_analysis_2006_ENG.pdf on 28 January 2021. 
forty thousand cases and sixty thousand. ${ }^{193}$ The ECtHR itself has admitted that the right to individual petition has been one of the major components of the human rights protection mechanism despite the challenge of case overload. ${ }^{194}$

The American system is also two-tier, with the Inter-American Commission and the Inter-American Court. ${ }^{195}$ Notably, only state parties and the InterAmerican Commission have locus standi before the Court. ${ }^{196}$ However, the InterAmerican Commission can refer a case, provided that the respondent state has accepted the jurisdiction of the Inter-American Court and that the state has failed to comply with recommendations issued by the Inter-American Commission unless there is a reasoned decision by the majority of the Commissioners to the contrary. ${ }^{197}$

Since the coming into operation of the Inter-American Court in 1980, the Commission has only referred three cases in its first decade. ${ }^{198}$ This was mainly due to states' failure to accept its jurisdiction. ${ }^{199}$ In a bid to have the American Convention enter into force, the US emphasised human rights as a key aspect of their foreign policy, lobbying its neighbours to ratify the American Convention on Human Rights resulting in many smaller powers ratifying it. ${ }^{200}$

There has been a progressive increment of cases submitted to the InterAmerican Court by the Inter-American Commission, to the tune of between twelve and twenty-three cases annually between 2003 and 2020. ${ }^{201}$ This has been occasioned by the adoption of the 2001 Rules of Procedure of the Inter-American Commission that reformed its practice, including the referral of cases. ${ }^{202}$ They provide that the facility of referrals shall be invoked if there is noncompliance with the Inter-American Commission's recommendations of the report on the merits of the case, unless there is a reasoned decision not to do so. ${ }^{203}$ This has

193 European Court of Human Rights analysis of statistics, 2020, 7 - https://www.echr.coe.int/ Documents/Stats_analysis_2020_ENG.pdf on 9 February 2021.

194 Mamatkulov and Askarov v Turkey ECHR, 2005, 122.

195 - http://www.oas.org/en/about/commission_human_rights.asp on 9 February 2021; - https:// www.corteidh.or.cr/historia.cfm?lang=en on 9 February 2021.

196 Article 61, American Convention on Human Rights.

197 Article 45, Rules of Procedure of the Inter-American Commission on Human Rights (2011).

198 Doedhar N, 'First contentious cases before the Inter-American Court of Human Rights' 3(1) American University International Law Review, 1988, 290.

199 Pinto M, 'The role of the Inter-American Commission and Court of Human Rights in the protection of human rights: Achievements and contemporary challenges' 20(2) Human Rights Brief, 2013, 1.

200 Shaver L, 'The Inter-American Human Rights System', 644.

201 - https://www.oas.org/en/iachr/decisions/cases.asp on 12 January 2021.

202 Goldman R, 'History and action', 883.

203 Article 44, Rules of Procedure of the Inter-American Commission on Human Rights (2001).

Vol. 6:1 (2021) p. 132 
been maintained even with the 2011 Rules of the Inter-American Commission. This feature is similar to the one in the 2010 Rules of the African Commission which allowed the African Commission, upon its discretion, to refer a case to the African Court upon noncompliance with its recommendations. ${ }^{204}$

David Padilla urged the African Commission not to repeat the European and American Commission's early mistakes of being reluctant in referring cases to the respective courts. ${ }^{205}$ The African system should, therefore, gain insights from the two older human rights systems that would inspire reform to overcome the present hurdles and ensure access to justice.

\section{Recommendations}

To prevent the cul-de-sac, this paper proposes three recommendations. Firstly, an amendment to the African Commission's 2020 Rules, with a key emphasis on Rule 130 which empowers the African Commission to refer cases to the African Court. It provides that the African Commission may only refer a communication to the African Court before determining its admissibility provided that the respondent state has ratified the Protocol on the African Court. ${ }^{206}$ It does not provide any other criteria to be used in making these referrals, such as the robust ones in the defunct Rule 118 in the 2010 Rules of the African Commission.

As it stands, it deeply regresses the progress that had been achieved by the Rule 118 in the 2010 Rules of the African Commission in clarifying how and when the African Commission may refer cases to the African Court. It would have been prudent to have Rule 118 under the 2010 Rules of the African Commission as the foundation of the referral of cases by the Commission by refining the criteria for greater clarity. This would have been a remarkable improvement, rather than creating an entirely different system for referrals that is scaled down, unclear and may result in difficulties in its execution.

Secondly, an establishment of a default procedure to be followed that ends in referral of cases to the African Court by the African Commission within a set period of time, pegged on a vote by the African Commission's commissioners. This is modelled, with slight variations, on the 2011 Rules of the Inter-American Commission and is to be restricted to cases where a state is noncompliant with the

\footnotetext{
204 Rule 118 (1), Rules of Procedure on the African Commission on Human and Peoples' Rights (2010).

205 Padilla D, 'An African human rights court: Reflections from the perspective of the Inter-American system' 2(1) African Human Rights Law Journal, 2002, 191.

206 Rule 130 (1), Rules of Procedure on the African Commission on Human and Peoples' Rights (2020).
}

Vol. 6:1 (2021) p. 133 
African Commission's recommendations or request for provisional measures. ${ }^{207}$ Despite a comparative study with the European and Inter-American system, this paper draws insights from the latter as it has the closest resemblance to the twotiered African human rights system. The former is left out as it is now a single system of human rights protection with the ECtHR only.

This would be effected by amending Rule 130 of the 2020 Rules of the African Commission to reflect, partly, Rule 45 of the 2011 Rules of the InterAmerican Commission. The African Commission could borrow some insights from there. One, it provides that in case of a state's noncompliance with its recommendations, the Inter-American Commission shall refer the case to the Inter-American Court. ${ }^{208}$ The use of the term 'shall' implies obligation, as opposed to discretion on whether or not to refer the case. The time frame should also be specified for all the grounds of referral, such as the one hundred and eighty days provided in the 2010 Rules of the African Commission. ${ }^{209}$

Two, a reasoned decision must be provided for non-referral if the majority of the commissioners decide so. ${ }^{210}$ This is particularly useful to prevent the failure to refer cases by the African Commission on unfounded, unclear or unstated grounds. Further, there should be express and concrete grounds for referral of cases to the African Court in addition to those of noncompliance. Even though the African Commission did not make much use of the grounds in its 2010 Rules, it goes without saying that resting the road to the Court on the sole ground in the Commission's 2020 Rules is a step down from the much more elaborate four-tier grounds in the 2010 Rules.

Rule 139 of the 2020 Rules charges the Commission with the mandate of amending its own rules but may consult the African Court as appropriate. ${ }^{211}$ In doing so, according to this paper's recommendation, it would help to promote access to justice for complainants who have exhausted local remedies and whose governments are complacent about effecting the Commission's recommendations and requests for provisional measures.

Lastly, this paper proposes that the African Court, in execution of its mandate, balances interests of justice and consideration of the background circumstances of cases referred to it by the African Commission. As noted earlier,

\footnotetext{
207 Article 44 and 45(1), Rules of Procedure of the Inter-American Commission on Human Rights (2009); Rule 118 (1) and (2), Rules of Procedure on the African Commission on Human and Peoples' Rights (2010).

208 Article 45 (1), Rules of Procedure of the Inter-American Commission on Human Rights.

209 Rule 118(1), Rules of Procedure on the African Commission on Human and Peoples' Rights 2020.

210 Article 45 (1), Rules of Procedure of the Inter-American Commission on Human Rights.

211 Rule 139 and 129 (4), Rules of Procedure on the African Commission on Human and Peoples' Rights 2020.
}

Vol. 6:1 (2021) p. 134 
most of the withdrawals from the four countries have been attributed partly to specific decisions against those states on sensitive socio-political matters. The African Court cannot therefore take a hands-off approach by failing to offer redress to individuals and NGOs that have exhausted local remedies and whose communications have been referred to it. This is because the African Court must diligently perform its mandate which is to complement the African Commission in the protection of human rights in Africa. ${ }^{212}$

One of the feasible avenues for achieving this balance would be applying situation-specific procedures and orders in dispensing with cases. To do this, the African Court would have to be keen in identifying the underlying issues, national standards of practice and the legitimate expectation of citizens of the respondent state regarding the matter. This can be realised in two ways; one, where the Court employs expedient procedures in determining the matter, so as to give reasonable time for implementation of its orders, and two, by issuing the most reasonable orders for the particular situation which does not unfairly infringe on the state's sovereignty. This is informed by Sègnonna Adjolohoun's analysis of the Sébastien Germain case. ${ }^{213}$

Adjolohoun proposes, in his analysis, that in the Sébastien Germain case, ${ }^{214}$ the African Court should have dealt with the case expediently and issued its order at least several months before the election for reasonable implementation, as it had received the application for the request of the provisional measures in January 2020, only to issue the order in April 2020, thirty days before the election scheduled for May 2020. ${ }^{215}$ Better yet, instead of suspending elections to secure the interest of one individual, the applicant, the Court should have sought to balance the interests of the applicant and his political party versus those of an entire nation, whose citizens had legitimate expectations of holding elections as constitutionally provided. ${ }^{216}$ The orders given would have hypothetically been to the effect that the respondent state ensures the applicant's participation in the elections, instead of suspending elections for the entire nation. ${ }^{217}$ The African Court is therefore encouraged to explore such alternatives and contextualize them to the cases before it, while still executing its mandate.

\footnotetext{
${ }^{212}$ Article 2, Protocol to the African Charter on Human and Peoples' Rights on the Establishment of an African Court of Human and People's Rights; Article 30, African Charter on Human and Peoples' Rights.

213 Adjolohoun S, 'A crisis of design and judicial practice? Curbing state disengagement from the African Court on Human and Peoples' Rights' 20(1) Africa Human Rights Law Journal, 2020, 22-23.

214 Sébastien Germain Ajavon v Republic of Benin (Judgment: Reparation), AfCHPR, Application No. 013/2017, 28 November 2019.

215 Adjolohoun S, 'A crisis of design and judicial practice?', 22-23.

216 Adjolohoun S, 'A crisis of design and judicial practice?', 24.

217 Adjolohoun S, 'A crisis of design and judicial practice?', 38.
} 


\section{Conclusion}

This paper has discussed two main barriers of direct access to the African Court, which together lead to the formation of the cul-de-sac. One, a great reluctance by states to the Article 34(6) declaration, while those that have made the declaration have begun withdrawing rapidly from it. Two, a failure by the African Commission to cover for this problem by bringing a sufficient number of cases to the African Court against states that have not made the declaration or that have withdrawn from it.

The authors began by discussing the Article 34(6) declaration through the drafting process of the African Court Protocol. We unravelled that African states portrayed a consistent reluctance to allow for an unfettered direct access for individuals and NGOs to the African Court. This stance was attributed to an inclination to guard their sovereignty and perceived non-interference in international affairs by the African Court.

To lay the framework for discussing the surge in withdrawals from the Article 34(6) declaration, we investigated how the declaration fits into the architecture of the VCLT. The discussions on the rapid withdrawals hitherto by the four states revealed a reincarnation of the African states' reluctance to have their internal affairs interfered with by the African Court.

This was followed by a discussion on the African Commission as the alternative path to the Court and its reluctance to refer cases. We focused on the three cases it has referred to the court, analysed instances where it could have referred but did not do so and lastly, conducted a comparative study with the European and Inter-American human rights system. We asserted that the rapid withdrawals together with the Commission's reluctance to refer cases, if sustained, would ultimately lead to the cul-de-sac. We concluded the paper by recommending an amendment to the Rule 130 of the 2020 Rules of the African Commission to a hybrid of Rule 118 of the 2010 Rules of the African Commission and Rule 45 of the 2011 Rules of Procedure of the Inter-American Commission.

In the research, we found that the African Court has fulfilled its mandate by exercising jurisdiction where it has been granted this power by states through their sovereign right of making the Article 34(6) declaration or where the African Commission has referred a case to it. This paper maintains the stance that if the status quo persists, this jurisdictional regime may collapse and eventually leave the continent with an African Court that is inaccessible to individuals and NGOs 